\title{
EFFECT OF ESTRADIOL, IMIPRAMINE AND FLUOXETINE ON BRAIN SEROTONIN LEVELS IN OVARIECTOMIZED-INDUCED OSTEOPOROTIC RATS \\ BY
}

\author{
Nora Zakaria ${ }^{1}$, Ahmed Esmat ${ }^{2}$, Hebatalla I. Ahmed ${ }^{3}$, Samar S Azab ${ }^{2}$ \\ FROM \\ ${ }^{1}$ Armed Forces Medical Complex- KobryEl-Qobba, Ministry of Defense \\ 2 Department of Pharmacology and Toxicology, Faculty of Pharmacy, Ain Shams \\ University \\ ${ }^{3}$ Department of Pharmacology and Toxicology, Faculty of Pharmacy (Girls), Al-Azhar \\ University
}

\begin{abstract}
Aim:

The present study aimed to determine the effect of Estradiol, Imipramine and Fluoxetine on brain serotonin levels in ovariectomized-induced osteoporotic rats and to investigate the effect of previous treatments on Electron Microscope results in rats.

\section{Methods:}

Rats were subjected to bilateral ovariectomy. After 2 weeks from operations, rats were treated with Estradiol, Imipramine and Fluoxetine for 14 days. At the end of 6 weeks animals were sacrificed and serotonin levels of brain tissue were determined. Electron microscope examination of femoral bone was also performed.
\end{abstract}

\section{Results:}

Treatment with Estradiol, Imipramine and Fluoxetine could treat depressive symptoms caused by ovariectomy which was observed in brain serotonin levels. Treatments could decrease the levels of brain serotonin by $28.73 \%, 35.25 \%$ and $32.14 \%$ respectively. Regarding Electron microscope, imipramine could partially improve bone structure while estradiol and fluoxetine could significantly restore bone mass compared to the corresponding osteoporosis group.

\section{Conclusion:}

In conclusion, Estradiol, imipramine and fluoxetine could treat depressive symptoms caused by ovariectomy in rats. Treatments have also shown restorative effects on bone structure in ovariectomized-induced osteoporotic rats.

\section{Keywords:}

Tricyclic antidepressants; selective serotonin reuptake inhibitors; ovariectomizedinduced osteoporosis; estradiol; imipramine; fluoxetine; serotonin. 


\section{Introduction}

Estrogens have positive effects on bone by inhibiting osteoclastic resorption which leads to an increase in bone mineral density (BMD) and a decrease in the risk of fractures. Interestingly, Because of the roles estrogen receptor $\alpha$ and estrogen receptor $\beta$ play in osteoclast apoptosis, the use of estrogen replacement therapy or estrogen progestin replacement therapy is effective for prevention of osteoporosis in post-menopausal women. Many studies show changes in lumbar spine, total hip, and femoral neck BMD; specifically, treatment with hormone replacement therapy increases bone density at the lumbar spine and reduced bone turnover markers at 2 years treatment (Cartwright et al., 2016) (Kharode et al., 2008) (Gennari et al., 2005). Selective estrogen receptor modulators (SERMs) have been shown to mimic the positive effects of estrogen on bone and cholesterol metabolism without being associated with its negative effects on reproductive tissues such as the uterus and breast breast (Kauffman and Bryant, 1995). The first clinically used drug in the class was tamoxifene, which is in use as a drug to treat estrogen receptor positive breast cancer. Tamoxifene does not seem to prevent fractures in women with breast cancer although BMD may increase. Raloxifene was marketed as a drug to treat and prevent osteoporosis. It was shown to increase BMD and to reduce the risk of vertebral fractures, although the risk of non-vertebral fractures did not seem to decrease (Delmas et al. 1997). Raloxifene was associated with a significant decrease in the risk of breast cancer. Other SERMs include lasofofoxifene, toremifene, idoxifene, arzoxifene, acolbifene and bazedoxifene along with a number of other compounds (Ariazi et al., 2006).

Tricyclic antidepressants (TCAs) are a class of medications that were discovered in the early 1950s. They are named after their chemical structure which contains three rings of atoms (Carson, 2000). TCAs are an important class of psychoactive drugs, which are widely used in the treatment of variety of depressive states and other psychiatric disorders (Maj et al., 1998). The TCAs are used primarily in the clinical treatment of mood disorders such as Major Depressive Disorder MDD, dysthymia, and treatment-resistant variants. They are also used in the treatment of a number of other medical disorders, including anxiety disorders such as generalized anxiety disorder, social phobia also known as social anxiety disorder and Parkinson's disease (Paumier et al., 2012). Imipramine, which is a prototypic tricyclic antidepressant, is regarded one of the most effective drugs and is still used to treat severe cases of depression although it causes unwanted side effects (Lo' pezMun oz et al., 2009). SSRIs are among the most widely prescribed drugs in psychiatry (Zito et al., 2002). Interestingly, it was found that the SSRIs were the top-rated antidepressants for all types of depression, with highest ratings for efficacy and tolerability given to citalopram and sertraline. Paroxetine was another first-line option while fluoxetine was rated high second line. Recent evidence continues to support the use of SSRIs and serotonin-norepinephrine reuptake inhibitors as first-line agents in the elderly (Alexopoulos, 2011) (Briggs et al., 2018). Fluoxetine is a selective serotonin reuptake inhibitor (SSRI) that is widely prescribed for the treatment of central nervous system linked cognitive, emotional, and behavioral disorders. The beneficial psychotropic effects of fluoxetine have led to its being used to treat disorders other than depression, including obsessive compulsive disorders and bulimia nervosa (Wong et al., 1995). 


\section{Aim of the work}

The aim of the present study was to determine the effect of Estradiol, Imipramine and Fluoxetine on brain serotonin levels in ovariectomized-induced osteoporotic rats and to investigate the effect of previous treatments on Electron Microscope results in rats.

\section{Materials and Methods}

\section{Experimental protocol:}

Forty eight adult female rats weighting from 150-200 grams were used. They were divided into six groups of 8 animals by random selection as follows (1) Control group, (2) Sham group, (3) Ovariectomy-induced osteoporotic group, (4) Estradiol treatment group at a dose $0.125 \mathrm{mg} / \mathrm{kg} /$ day (Huber et al., 2007), (5) Imipramine treatment group at a dose 15 $\mathrm{mg} / \mathrm{kg} /$ day (Cieślik et al., 2007), (6) Fluoxetine treatment group at a dose $20 \mathrm{mg} / \mathrm{kg} / \mathrm{day}$ (Erman et al., 2015). Osteoporosis was induced by bilateral ovariectomy in groups 3, 4, 5 and 6. Rats were anaesethized by Ketamine, Xylazine and Midazolam combination at doses $75 \mathrm{mg} / \mathrm{kg}, 3 \mathrm{mg} / \mathrm{kg}$ and $3 \mathrm{mg} / \mathrm{kg}$ respectively. A short incision is made halfway between the edge of ribcage and the base of the tail, abdominal muscle wall incision is made, ovary is exteriorized ligated and excised then the remaining tissue is replaced into peritoneal cavity and skin is sutured. Two weeks after operations, treatments started with Estradiol, Imipramine and Fluoxetine for 14 consecutive days. Estradiol was dissolved in corn oil, Imipramine $\mathrm{HCl}$ and Fluoxetine $\mathrm{HCl}$ were dissolved in water for injection. Two weeks after last day of treatment, rats were sacrificed. Rats were decapitated and brains were excised and preserved at $-80^{\circ} \mathrm{C}$ until analyzed. The femoral bones were excised, cleaned from soft tissue and preserved at $-80^{\circ} \mathrm{C}$ until analyzed.

\section{Brain Serotonin levels:}

Brain serotonin levels can be determined by fluorometric assay, the catecholamines are first oxidized to their "adrenochromes", and then re-arranged to their "adrenolutins", which are then detected by specific fluorescence at particular wavelengths of excitation and emission (Ciarolone, 1978). The fluorescence was read at excitation $355 \mathrm{~nm}$ and emission at $470 \mathrm{~nm}$ using Hitachi (F3010 model) spectrophotofluorometer.

\section{Electron Microscope:}

Two femoral heads of the proximal femur were selected from each group rat, Femur heads were cut into $1 \times 1 \times 1 \mathrm{~mm}$ pieces and washed in phosphate-buffered saline (PBS). The samples were placed in $2.5 \%$ glutaric aldehyde solution for $3 \mathrm{~h}$ at $4{ }^{\circ} \mathrm{C}$ and samples were then decalcified in 5\% ethylenediaminetetraacetic acid (EDTA) for three weeks by changing EDTA solution every week. Subsequently, the samples were fixed in $1 \%$ osmium tetroxide, embedded and cut into thin sections with Epon812. Finally, samples were double-stained using uranyl acetate and lead citrate and observed using transmission electron microscope (Zheng et al., 2016).

\section{Statistical analysis:}

Statistical analyses were performed using Graph Pad Prism (version 5) software. All parametric data are expressed as arithmetic mean values with their standard error of mean (mean \pm SEM). Statistical significance of differences for parametric data was 
calculated using one-way analysis of variance (ANOVA) followed by post hoc Tukey Comparison test. Statistical tests were used for comparisons between groups, and statistical significance was established at $\mathrm{P}<0.05$ (Abdel-Daim et al., 2015).

\section{Results}

\section{Effects of Estradiol, Imipramine and Fluoxetine on brain serotonin levels:}

Table 1 revealed the effect of treatments with estradiol $(0.125 \mathrm{mg} / \mathrm{kg})$, imipramine $(15 \mathrm{mg} / \mathrm{kg})$ and fluoxetine $(20 \mathrm{mg} / \mathrm{kg})$ on brain serotonin levels. Treatment with estradiol, imipramine and fluoxetine for 2 weeks corrected the defect in brain serotonin levels that was noticed in untreated groups. It was found that there was a significant $88.86 \%$ increase in the brain tissue serotonin levels in the osteoporosis rats compared to the control group. While, treatments decreased the serotonin levels value by about $28.73 \%, 35.25 \%$ and $32.14 \%$ respectively compared to the osteoporosis group.

Table (1): Effects of Estradiol, Imipramine and Fluoxetine on the Serotonin levels:

\begin{tabular}{|l|c|c|c|c|c|c|}
\hline Groups & Control & Sham & $\begin{array}{c}\text { Osteo- } \\
\text { porosis }\end{array}$ & $\begin{array}{c}\text { Estradiol } \\
\mathbf{( 0 . 1 2 5} \\
\mathbf{m g} / \mathbf{k g})\end{array}$ & $\begin{array}{c}\text { Imipramine } \\
\mathbf{( 1 5} \\
\mathbf{m g} / \mathbf{k g})\end{array}$ & $\begin{array}{c}\text { Fluoxetine } \\
\mathbf{( 2 0} \\
\mathbf{m g} / \mathbf{k g})\end{array}$ \\
\hline $\begin{array}{l}\text { Serotonin } \\
\text { levels (pmol } \\
\text { /mg protein) }\end{array}$ & $\begin{array}{c}3.41 \pm 0.1 \\
7\end{array}$ & $\begin{array}{c}3.68 \pm 0.2 \\
0\end{array}$ & $\begin{array}{c}6.44^{\mathrm{a}} \\
\pm 0.43\end{array}$ & $\begin{array}{c}4.59^{\mathrm{b}} \pm 0.3 \\
2\end{array}$ & $4.17^{\mathrm{b}} \pm 0.31$ & $4.37^{\mathrm{b}} \pm 0.43$ \\
\hline $\begin{array}{l}\text { Percentage of } \\
\text { change from } \\
\text { control group }\end{array}$ & $100 \%$ & $107.92 \%$ & $188.86 \%$ & $134.6 \%$ & $122.29 \%$ & $128.15 \%$ \\
\hline
\end{tabular}

Data are expressed as the mean \pm SEM $(n=6)$ and analyzed using one-way ANOVA followed by post hoc Tukey comparison test.

a: Significantly different from the corresponding control group at $\mathrm{P}<0.05$.

b: Significantly different from the corresponding osteoporosis group at $\mathrm{P}<0.05$.

Electron Microscope:

Electron Microscope examination of the rat femur bone revealed that control showed normal well preserved osteoblastic cell with good preservation of its organelles, such as Golgi complex, granular endoplasmic reticulum and mitochondria (Figure 1A). Besides, EM examination of the rat femur bone revealed that sham groups also showed normal cell with good preservation of its organelles, such as Golgi complex, granular endoplasmic reticulum and mitochondria (Figure 1B).

On the other hand, femur bone from the ovariectomy-induced osteoporosis group showed showing apoptosis of the osteoblast (Figure 1C). Interestingly, estradiol treatment at a dose of $(0.125 \mathrm{mg} / \mathrm{kg})$ for 2 weeks could attenuate these changes, showing improved osteoblastic cell compared to osteoporosis group with organelles such as the rough 
endoplasmic reticulum, mitochondria and Golgi apparatus being visible and active (Figure 1D).

Imipramine $(15 \mathrm{mg} / \mathrm{kg})$ group demonstrated partially improved osteoblastic cell compared to osteoporosis group (Figure 1E). Besides, Fluoxetine $(20 \mathrm{mg} / \mathrm{kg}$ ) group demonstrated improved osteoblastic cell compared to osteoporosis group (Figure 1F).

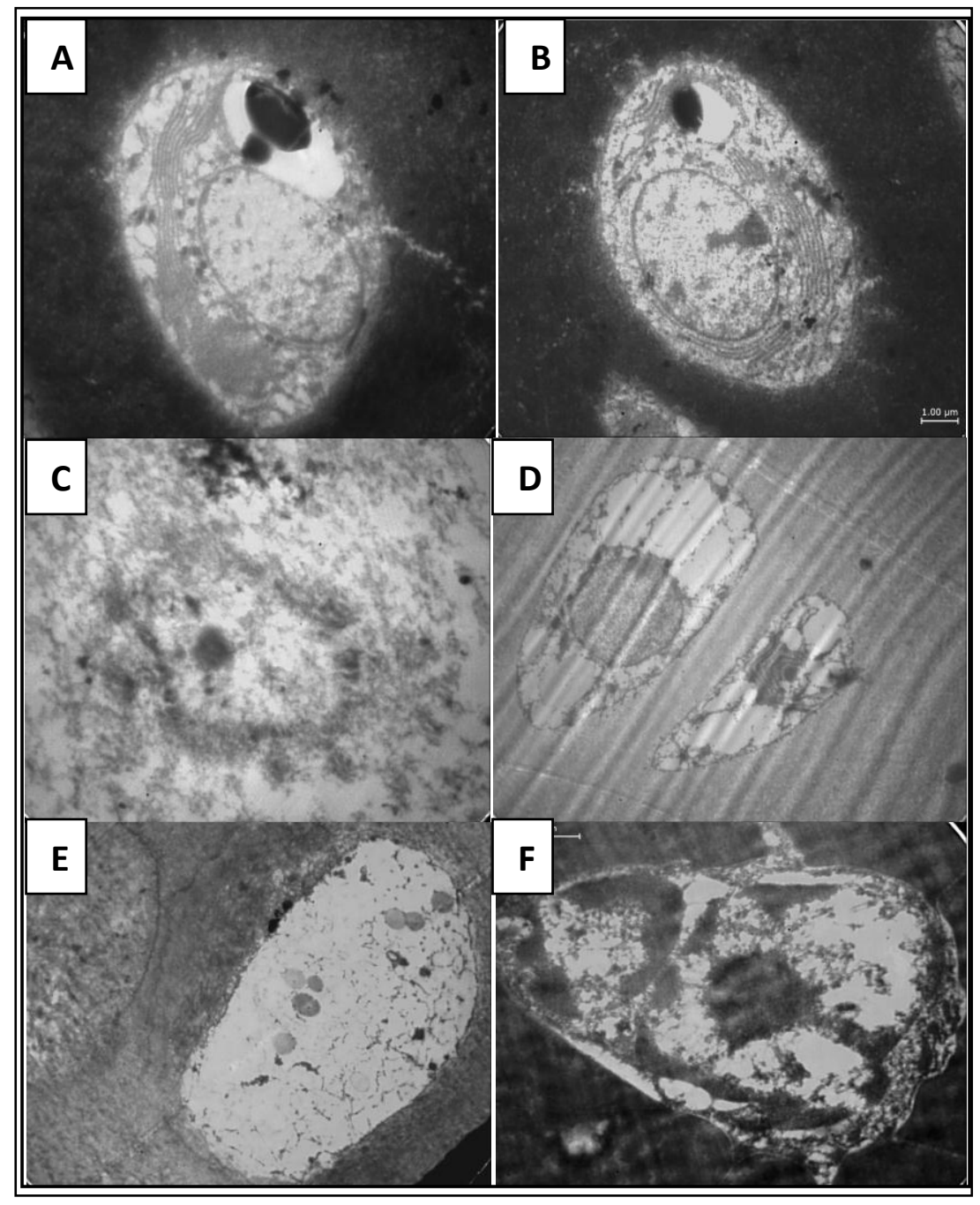

Figure (1): Electron Microscope images of femur bone of A) control group, B) sham group, C) osteoporosis group, D) estradiol group, E) imipramine group, F) fluoxetine group 


\section{Discussion:}

Hormone replacement therapy (HRT) has been publicly recognized as the first choice prevention and treatment for postmenopausal osteoporosis. Because of the roles estrogen receptor $\alpha$ and estrogen receptor $\beta$ play in osteoclast apoptosis, the use of estrogen replacement therapy or estrogen progestin (hormone) replacement therapy is effective for prevention of osteoporosis in post-menopausal women (Wang et al., 2014). Selective estrogen receptor modulators have been shown to mimic the positive effects of estrogen on bone and cholesterol metabolism without being associated with its negative effects on reproductive tissues such as the uterus and breast (Kauffman and Bryant, 1995). On the other hand, Imipramine was discovered in 1951 and was introduced for medical use in 1957. It was the first TCA to be marketed. Imipramine and the other TCAs have decreased in use in recent decades due to the introduction of the SSRIs, which have fewer side effects and are safer in overdose. Imipramine acts as an inhibitor of serotonin and norepinephrine reuptake (Slattery et al. 2004). SSRIs are effective antidepressants that possess an advantageous safety profile, especially concerning overdose. In most countries, fluoxetine was the first SSRI that became available for clinical use. Since then, fluoxetine has become one of the most widely used antidepressants (Hiemke and Hartter, 2000).

The current results demonstrated that treatment of ovareictomized osteoporotic rats with estradiol, imipramine and fluoxetine could reverse the depression resulting from ovariectomy and osteoporosis. Brain tissue levels of serotonin were significantly increased in the osteoporotic rats, compared to the corresponding control groups. Treatment with estradiol, imipramine and fluoxetine significantly decreased these elevated values, compared to the corresponding osteoporotic groups. The increased tissue content of both 5HT in osteoporotic rats might reflect either increased synthesis of 5-HT or decreased elimination of 5-HT. According to the 5-HT hypothesis of depression, depressive disorder is caused by a general decrease in 5-HT neurotransmission (Maes and Meltzer, 1995). A decreased 5-HT postsynaptic neurotransmission in specific limbic sites may lead to an increase in terminal 5-HT synthesis via a compensatory feedback mechanism. In osteoporotic rats, a reduction in the elimination of 5-HT could be due to a decreased activity of monoamine oxidase. However, a decreased elimination could be caused by a decreased release of 5-HT from nerve terminals, because elimination from brain tissue requires exposure of the compounds to the extra-cellular space (Stachowiak et al., 1986). Also, a decreased 5-HT release from nerve terminals may cause increased synthesis via a compensatory feedback mechanism (Adell et al., 1988).

Regarding EM examination, rat femur bone sections of the osteoporosis group revealed major bone mass loss. Treatment of osteoporotic rats with estradiol and fluoxetine markedly restored bone mass while treatment with imipramine caused partial restoration of bone mass. Interestingly, the ultra structural analysis of the bone tissue of intact bone showed well preserved cells and bone matrix. Analysis showed also a good preservation of osteoblastic cells organelles, such as Golgi complex, granular endoplasmic reticulum and mitochondria (Pitol et al., 2007). Furthermore, studies observed that arrangement of collagen fibers in the osteoporotic treated groups were more tightly packed and regular compared with the OVX group, while organelles such as the rough endoplasmic reticulum, 
mitochondria and Golgi apparatus were visible and active, indicating micro proliferation of bone (Zheng et al., 2016).

In conclusion, treatment with estradiol, imipramine and fluoxetine could reverse depression resulting from osteoporosis in ovareictomized rats. Furthermore, Estradiol, imipramine and fluoxetine treatments have shown to have a restorative action on bone tissue when compared to ovariectomized induced osteoporotic rats.

\section{REFERENCES}

Abdel-Daim MM, Farouk SM, Madkour FF, Azab SS, (2015). Anti-inflammatory and immunomodulatory effects of Spirulina platensis in comparison to Dunaliella salina in acetic acid-induced rat experimental colitis. Immunopharmacol Immunotoxicol. 37, 126-139.

Adell A, Garcia-Marquez C, Armario A, and Gelpi E, (1988). Chronic stress increases serotonin and noradrenaline in rat brain and sensitizes their responses to further acute stress. I. Neuro-chem. 50, 1678-1681.

Alexopoulos GS, (2011). Pharmacotherapy for late-life depression. J Clin Psychiatry. 72(1):e04.

Ariazi E, Ariazi J, Cordera F, Jordan V, (2006). Estrogen receptors as therapeutic targets in breast cancer. Curr To pMed Chem. 6:181-202.

Briggs R, Carey D, McNicholas T, Claffey P, Nolan H, Kennelly SP, Kenny RA, (2018). The association between antidepressant use and orthostatic hypotension in older people: a matched cohort study. J Am Soc Hypertens. pii: S19331711(18)30163-3.

Carson VB, (2000). Mental health nursing: the nurse-patient journey W.B. Saunders. ISBN. 978-0-7216-8053-8. pp. 423

Cartwright B, Robinson J, Seed PT, Fogelman I, Rymer J, (2016). Hormone replacement therapy versus the combined oral contraceptive pill in premature ovarian failure: a randomized controlled trial of the effects on bone mineral density. J. Clin. Endocrinol. Metab. 101 3497-3505.

Ciarolone AE, (1978). Further modification ofa fluorometric method foranalyzing brain amines. Microchemical Journal. 23: 9-12.

Cieślik K, Klenk-Majewska B, Danilczuk Z, Wróbel A, Lupina T, Ossowska G, (2007). Influence of zinc supplementation on imipramine effect in a chronic unpredictable stress (CUS) model in rats. Pharmacol Rep. 59(1):46-52.

Delmas P, Bjarnason N, Mitlak B, Ravoux A, Shah A, Huster W et al, (1997). Effects of raloxifene on bone mineral density, serum cholesterol concentrations, and uterine endometrium in postmenopausal women. N Engl J Med.337:16411647.

Erman H, Guner I, Yaman MO, Uzun DD, Gelisgen R, Aksu U, Yelmen N, Sahin G, Uzun H, (2015). The effects of fluoxetine on circulating oxidative damage 
parameters in rats exposed to aortic ischemia-reperfusion. Eur $\mathrm{J}$ Pharmacol. 749:56-61.

Gennari L, Merlotti D, De Paola V, Calabrò A, Becherini L, Martini G, Nuti R, (2005). Estrogen receptor gene polymorphisms and the genetics of osteoporosis: A HuGE review. Am J Epidemiol. 161:307-320.

Hiemke C, Hartter S, (2000). Pharmacokinetics of selective serotonin reuptake inhibitors. Pharmacol Ther. 85:11-28

Huber C, Collishaw S, Mosley JR, Reeve J, Noble BS, (2007). Selective estrogen receptor modulator inhibits osteocyte apoptosis during abrupt estrogen withdrawal: implications for bone quality maintenance. Calcif Tissue Int 81, 139-144.

Kauffman RF, Bryant HU, (1995). Effective therapeutic management of the postmenopausal state will be a cornerstone in strategies for preserving or improving women's health in the 21 stcentury. Selective estrogen receptor modulators. Drug News Perspect. 8:531-539

Kharode Y, Bodine P, Miller C, Lyttle C, Komm B, (2008). The pairing of a selective estrogen receptor modulator, bazedoxifene, with conjugated estrogens as a new paradigm for the treatment of menopausal symptoms and osteoporosis prevention. Endocrinology. 149:6084-6091.

Lo' pez-Mun oz F, Alamo C, (2009). Monoaminergic neurotransmission: the history of the discovery of antidepressants from 1950s until today. Curr Pharm Des. $15: 1563-1586$

Maes M, Meltzer HY, (1995). The serotonin hypothesis of major depression, in Psychopharmacology: The Fourth Generation of Progress ((Bloom F. E. and K Kupfer D. J., eds), pp. 933-944. Raven Press, New York.

Maj J, Dziedzicka-Wasylewska M, Rogoz R, Rogóz Z, (1998). Effect of antidepressant drugs administered repeatedly on the dopamine D3 receptors in the rat brain. Eur $\mathbf{J}$ Pharmacol. 12;351(1):31-7.

Paumier KL, Siderowf AD, Auinger P, Oakes D, Madhavan L, Espay A J, Revilla FJ, Collier TJ, (2012). Parkinson Study Group Genetics Epidemiology Working Group. "Tricyclic antidepressants delay the need for dopaminergic therapy in early Parkinson's disease". Movement Disorders. 27 (7): 880-7.

Pitol Dimitrius Leonardo, Caetano Flavio Henrique, Lunardi Laurelúcia Orive, (2007). Microwave-induced fast decalcification of rat bone for electron microscopic analysis: an ultrastructural and cytochemical study. Braz. Dent. J. vol.18 no. 2

Slattery DA, Hudson AL, Nutt DJ, (2004). Invited review: the evolution of antidepressant mechanisms. Fundam Clin Pharma-col. 18:1-21 
Stachowiak MK, Stricker EM, Jacohy JH, and Zigmond MJ, (1986). Increased tryptophan activity in serotonergic nerve terminals spared by 5,7dihydroxytryptamine. Biochem. Pharmacot. 35, 1241-1248.

Wang Y, Yang X, Li X, He X and Zhao Y, (2014). Knowledge and personal use of menopausal hormone therapy among Chinese Obstetrician-gynecologists: Results of a survey. Menopause. 21:1190-1196.

Wong DT, Bymaster FP, and Engleman EA, (1995). Prozac (fluoxetine, Lilly 110140), the first selective serotonin uptake inhibitor and an antidepressant drug: twenty years since its first publication. Life Sci. 57:411 -441 .

Zheng Xiaohua, Huang Huijuan, Zheng Xiaobing, Li Baoheng, (2016). Olive oil exhibits osteoprotection in ovariectomized rats without estrogenic effects. Research and Experimental Medicine. Volume 11 Issue 5 1881-1888.

Zito JM, Safer DJ, DosReis S, Gardner JF, Soeken K, et al., (2002). Rising prevalence of antidepressants among US youths. Pediatrics. 109: 721-727.
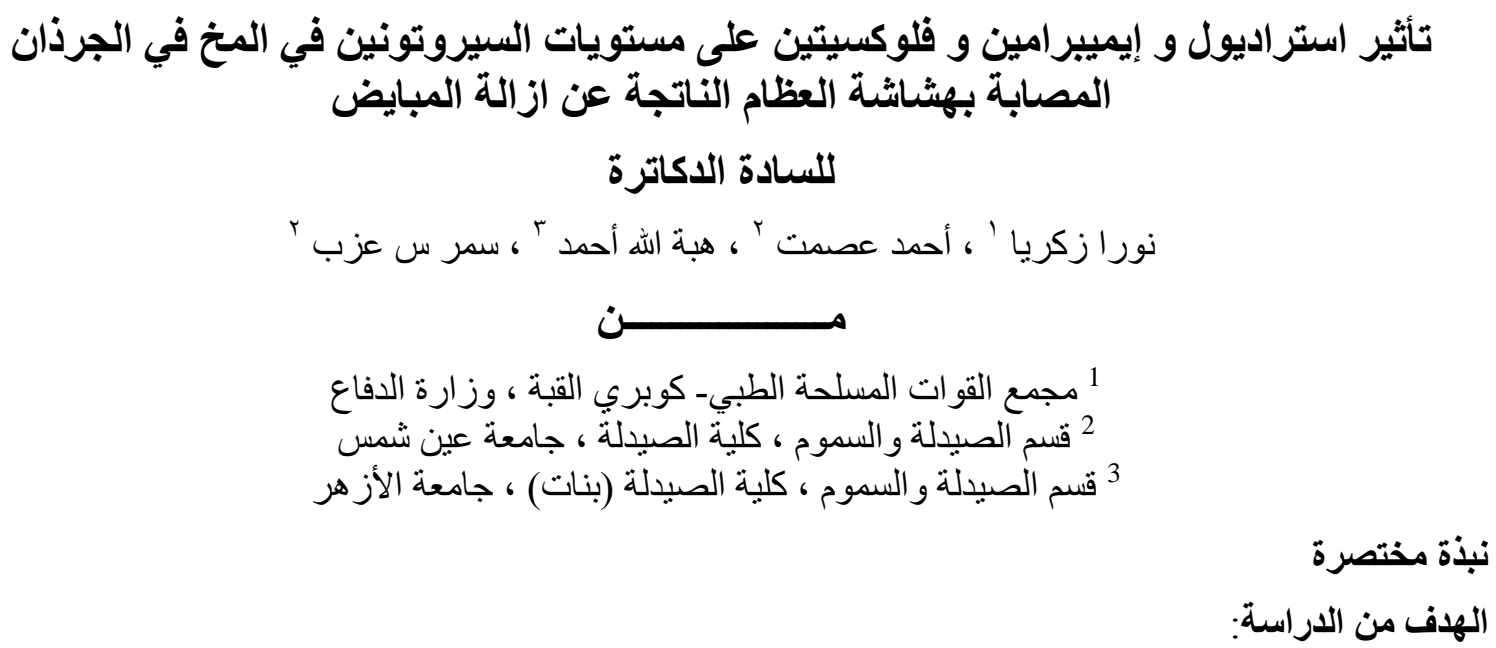

تهدف الدراسة الحالية إلى التوصل الي تأثثير استر اديول ، إيميير امين وفلوكستين على مستويات السيروتونين

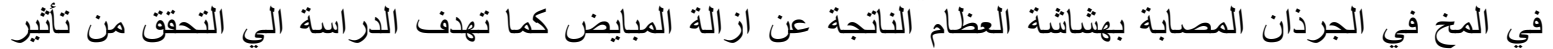

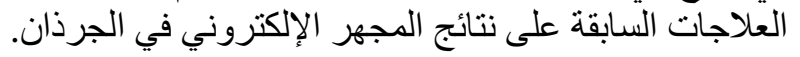

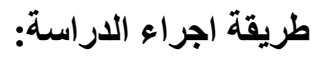

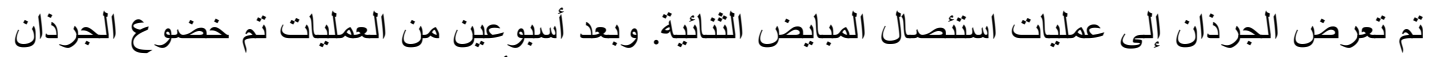

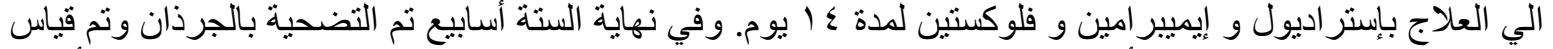
مستويات السيروتونين في أنسجة المخ كما نم إجراء فحص المسن المجر الإلكتروني لعظام الفخذ أيضا. 
نتائج الدراسة:

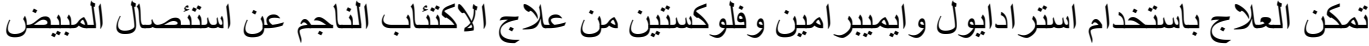

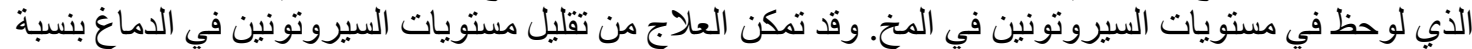

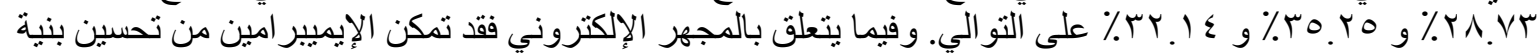

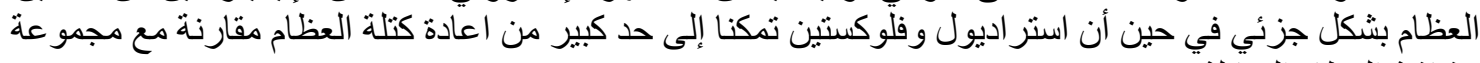
هشاشة العظام المقابلة.

الاستتناج:

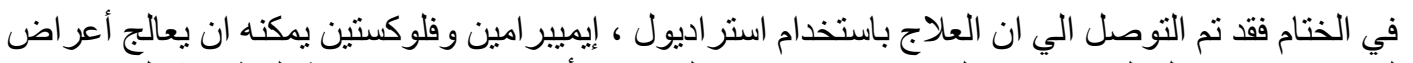

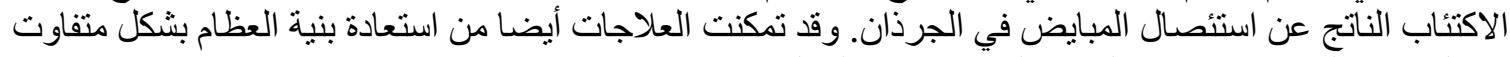

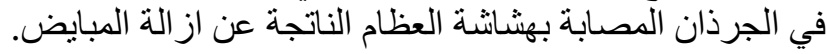

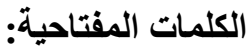

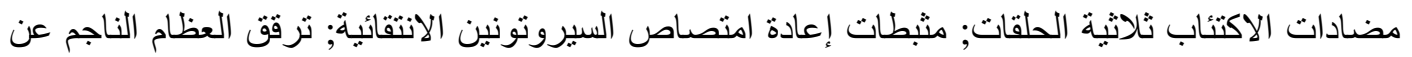
از الة المبايض ;استر اديول ;إيميير امين ;فلوكستين ;سيرونونين. 